\title{
Early Diagnosis of Acute Kidney Injury: The Promise of Novel Biomarkers
}

\author{
Sachin S. Soni ${ }^{a, b}$, e Claudio Ronco ${ }^{a, c}$ Nevin Katz ${ }^{d}$ Dinna N. Cruz ${ }^{a, c}$ \\ a San Bortolo Hospital, Vicenza, Italy; ${ }^{b}$ Mediciti Hospitals, Hyderabad, India; International Renal Research Institute, \\ Vicenza, Italy; ${ }^{d}$ Department of Surgery, George Washington University, Washington, D.C., USA; e Seth Nandlal \\ Dhoot Hospital, Aurangabad, India
}

\section{Key Words}

Acute renal failure - Acute kidney injury · Acute Kidney Injury Network (AKIN) • RIFLE Classification · Neutrophil gelatinase-associated lipocalin

\begin{abstract}
The incidence of acute kidney injury (AKI) formerly referred to as acute renal failure (ARF) is increasing to epidemic proportions. Development of AKI portends excessive morbidity and mortality. AKI is associated with prolonged hospital stay, increased healthcare costs and high mortality especially in critically ill patients. The mortality rate has remained largely unchanged for many decades. Delay in the diagnosis of AKI using conventional biomarkers like urine output and serum creatinine has been one of the important obstacles in applying effective early interventions. Several new biomarkers are being evaluated in a quest for early diagnosis of AKI, among which neutrophil gelatinase-associated lipocalin (NGAL) appears to be one of the most promising. This review summarizes the recent literature on these biomarkers.
\end{abstract}

Copyright $\odot 2009$ S. Karger AG, Base

\section{Introduction}

Acute kidney injury (AKI) formerly referred to as acute renal failure (ARF) is a common clinical problem. The term ARF was first coined by Homer W. Smith [1] in his textbook in which he referred to kidney dysfunction related to traumatic injuries. Since then this term has been commonly used in clinical practice and medical literature. ARF is the generic term for an abrupt and sustained decrease in renal function resulting in retention of nitrogenous (urea and creatinine) and non-nitrogenous waste products [2]. Until recently there was no clear definition of ARF. In 2002, the Acute Dialysis Quality Initiative (ADQI) workgroup found that over 30 definitions for ARF were used in the literature. The definitions varied from a $25 \%$ increase over baseline serum creatinine to the need for dialysis [3]. The development of consensus definition of AKI was an important priority $[3,4]$. The term AKI has been proposed to replace ARF, as acute decline in renal function is generally secondary to an injury which leads to functional and structural changes in the kidneys. The term AKI is also intended to reflect the entire spectrum of ARF.

S.S. Soni is supported by a fellowship grant from the International Society of Nephrology.

Dr. Dinna N. Cruz

Nephrology Dialysis and Transplantation, San Bortolo Hospital

Via Rodolfi, 37, IT-36100 Vicenza (Italy)

Tel. +390444753 650, Fax +390444753949

E-Maildinnacruzmd@yahoo.com 
Table 1. RIFLE and AKIN criteria for diagnosis of AKI

\begin{tabular}{|c|c|c|}
\hline \multicolumn{3}{|c|}{ RIFLE criteria } \\
\hline Class & GFR criteria & Urine output criteria \\
\hline Risk & $\begin{array}{l}\text { Increased creatinine } \times 1.5 \\
\text { or GFR decrease }>25 \%\end{array}$ & $\begin{array}{l}\text { Urine output } \\
<0.5 \mathrm{ml} / \mathrm{kg} / \mathrm{h} \times 6 \mathrm{~h}\end{array}$ \\
\hline Injury & $\begin{array}{l}\text { Increased creatinine } \times 2 \\
\text { or GFR decrease }>50 \%\end{array}$ & $\begin{array}{l}\text { Urine output } \\
<0.5 \mathrm{ml} / \mathrm{kg} / \mathrm{h} \times 12 \mathrm{~h}\end{array}$ \\
\hline Failure & $\begin{array}{l}\text { Increased creatinine } \times 3 \\
\text { or GFR decrease }>75 \% \\
\text { or creatinine } \geq 4 \mathrm{mg} / \mathrm{dl} \\
(\text { acute rise of } \geq 0.5 \mathrm{mg} / \mathrm{dl} \text { ) }\end{array}$ & $\begin{array}{l}\text { Urine output } \\
<0.3 \mathrm{ml} / \mathrm{kg} / \mathrm{h} \times 24 \mathrm{~h} \\
\text { or anuria } \times 12 \mathrm{~h}\end{array}$ \\
\hline Loss & $\begin{array}{l}\text { Persistent AKI }=\text { complete loss } \\
\text { of renal function }>4 \text { weeks }\end{array}$ & \\
\hline ESKD & $\begin{array}{l}\text { End-stage kidney disease }>3 \\
\text { months }\end{array}$ & \\
\hline \multicolumn{3}{|c|}{ AKIN classification } \\
\hline Stage & Serum creatinine criteria & Urine output criteria \\
\hline 1 & $\begin{array}{l}\text { Increase in serum creatinine of } \\
\geq 0.3 \mathrm{mg} / \mathrm{dl} \\
\text { or increase to } \geq 150 \text { to } 200 \% \text { from } \\
\text { baseline }\end{array}$ & $\begin{array}{l}\text { Urine output } \\
<0.5 \mathrm{ml} / \mathrm{kg} / \mathrm{h} \times 6 \mathrm{~h}\end{array}$ \\
\hline 2 & $\begin{array}{l}\text { Increase in serum creatinine to } \\
>200 \text { to } 300 \% \text { from baseline }\end{array}$ & $\begin{array}{l}\text { Urine output } \\
<0.5 \mathrm{ml} / \mathrm{kg} / \mathrm{h} \times 12 \mathrm{~h}\end{array}$ \\
\hline 3 & $\begin{array}{l}\text { Increase in serum creatinine to } \\
>300 \% \text { from baseline } \\
\text { (or serum creatinine of } \geq 4.0 \mathrm{mg} / \\
\text { dl with an acute increase of at } \\
\text { least } 0.5 \mathrm{mg} / \mathrm{dl} \text { ) }\end{array}$ & $\begin{array}{l}\text { Urine output } \\
<0.3 \mathrm{ml} / \mathrm{kg} / \mathrm{h} \times 24 \mathrm{~h} \\
\text { or anuria } \times 12 \mathrm{~h}\end{array}$ \\
\hline
\end{tabular}

RIFLE = Risk-Injury-Failure-Loss-End-stage kidney disease; AKIN = Acute Kidney Injury Network; GFR = glomerular filtration rate; $\mathrm{AKI}=$ acute kidney injury.

\section{RIFLE and AKIN}

In order to meet the need for uniform definition, early detection and grading of severity of AKI, RIFLE classification [Risk-Injury-Failure-Loss-End-stage kidney disease (ESKD)] (table 1) was developed by ADQI [5]. The first three represent the level of severity and last two are outcome criteria. This definition has been validated in various studies. Worse RIFLE class is found to correlate with increased mortality in many studies [6-8]. For further refinement of the definition of AKI, the Acute Kidney Injury Network (AKIN) was created, which proposed a modified version of the RIFLE classification, also known as the AKIN criteria [9]. The important modifications in
AKIN criteria over the RIFLE classification include: (a) the outcome criteria are removed and severity criteria are designated as stage 1,2 and 3; (b) the 'risk' category of RIFLE is broadened to include an increase in serum creatinine of at least $0.3 \mathrm{mg} / \mathrm{dl}$ even if this does not reach the $50 \%$ threshold; (c) a 48-hour window is set for the first documentation of any stage, and (d) any patient treated with renal replacement therapy is categorized as stage 3 regardless of serum creatinine or urine output. The AKIN criteria were found to improve sensitivity of detection of AKI compared to the RIFLE classification by Lopes et al. [10]. However, a retrospective evaluation of Australia and New Zealand Intensive Care Society (ANZICS) database did not reveal any significant difference [11].

\section{Epidemiology of AKI}

The reported incidence of AKI varies from $5 \%$ in hospitalized patients to $30-50 \%$ in intensive care units (ICUs) [12]. The incidence varies with the definition employed and the study setting. The incidence of community-acquired severe AKI (defined as serum creatinine $>5.68$ $\mathrm{mg} / \mathrm{dl}$ ) was found to be 172 cases per million adults per year, of which 22 per million received renal replacement therapy (RRT) in a British study [13]. In another study, in a community setting, the incidence of non-dialysis requiring AKI was found to be 384.1 per 100,000 personyears and that of dialysis requiring AKI was 24.4 per 100,000 person-years [14]. In ICUs, $4.9 \%$ patients required RRT in a study reported by Metnitz et al. [15] while AKI was reported to occur in around 19\% patients with moderate sepsis, in $23 \%$ with severe sepsis, and in $51 \%$ of those with septic shock and positive blood cultures [16]. In a prospective multinational observational study involving critically ill patients from 54 hospitals in 23 countries, $5.7 \%$ patients developed AKI with the majority requiring RRT [17].

Recently, many studies have reported AKI epidemiology using RIFLE criteria. In a population-based study from Scotland, the incidence of AKI and acute over CKD was found to be 1,811 and 336 per million population, respectively [18]. In a study from north-east Italy, AKI occurred in $10.8 \%$ of all ICU patients when RIFLE criteria were applied at the time of admission [8], while it occurred in $67.2 \%$ of ICU patients when RIFLE criteria were applied at peak creatinine during an ICU stay in another study [7]. 


\section{Etiology of AKI}

The causes of AKI are traditionally divided into three categories: prerenal, intrinsic renal and postrenal. The prerenal azotemia indicates physiological response of the kidney to hypoperfusion [19] which could be a result of an absolute decrease in circulating volume or reduction in the effective circulating volume. The postrenal category refers to the conditions causing obstruction to urine outflow. The major pathological correlate of intrinsic AKI is acute tubular necrosis (ATN). It is a common clinical practice to use the terms intrinsic AKI and ATN interchangeably. Prerenal azotemia and ATN are considered to represent the continuum of the same pathophysiological process and together account for three-quarters of AKI cases [20]. The etiology of AKI is variable across the world. In developing countries, AKI is the disease of younger subjects and community-acquired cases are common. Acute diarrheal diseases, acute glomerulonephritis, tropical infections (mainly malaria and leptospirosis), environmental agents and snake bite are the common causes of AKI in developing countries [21, 22]. In developed countries AKI is common in the elderly and hospital-acquired causes dominate [21]. In the multinational study of AKI in critically ill patients [17], septic shock was the most common etiology (47.5\%) followed by postsurgical AKI (34\%), cardiogenic shock (27\%), hypovolemia (26\%) and drugs (19\%), with more than one factor involved in many cases. Acute radiocontrast nephropathy is an important cause of AKI in hospitalized patients undergoing contrast-based procedures [20].

\section{Pathophysiology of Intrinsic AKI}

Pathophysiologically, intrinsic AKI can be due to ischemia, toxins or sepsis with more than one factor playing its part concomitantly. Derangements of vascular and tubular compartments of the kidneys are proposed to contribute to the marked decrease in glomerular filtration rate in AKI [2]. The vascular events include severe and persistent renal vasoconstriction and congestion in the outer medullary compartment. Renal vasoconstriction decreases the renal blood flow to approximately $50 \%$ of normal. The outer medullary congestion decreases tissue oxygen delivery to the already hypoxic S3 segment of proximal collecting tubule (PCT) and the medullary thick ascending limb of the loop of Henle [23]. The tubular events include tubular obstruction, backleak and increased tubuloglomerular feedback. In sepsis, renal vaso- constriction in the presence of systemic vasodilation is considered to be the hallmark, although this viewpoint has been challenged recently. Wan et al. [24] have proposed that renal vasodilation and hyperemia could be more pivotal to septic AKI than renal vasoconstriction and ischemia and pathologically tubular cell apoptosis or tubular cell dysfunction could be more common than tubular necrosis. The reader is referred to recent publications for detailed mechanisms of AKI in ischemia [23], toxins [16] and sepsis [25].

\section{Complications of AKI}

\section{Increased Length of Hospital Stay}

Development of AKI is associated with a longer ICU and hospital stay. Even patients with mild AKI (RIFLE class $\mathrm{R}$ ) have a longer hospital stay than those without AKI and this trend continues in a stepwise manner with the worse RIFLE class having longer hospital stay [26, 27]. In a study by Hoste et al. [6], patients with AKI had a longer hospital stay (RIFLE class R 8 days, Injury 10 days, Failure 16 days) compared to the patients without AKI (6 days).

\section{Increased Mortality and Morbidity}

Despite impressive advances in treatment, mortality in critically ill patients with AKI continues to remain very high. The mortality rate of AKI was around 91\% during the Second World War [28]. In a systematic review of the literature from 1970 to 2004, Ympa et al. [29] observed an unchanged mortality of around 50\% from 80 studies. A recent study has reported a hospital mortality rate of $60.3 \%$ [17]. A multicenter evaluation of RIFLE criteria showed a crude hospital mortality of $17.9 \%$ for Risk, $27.7 \%$ for Injury and $33.2 \%$ for Failure criteria of the RIFLE classification [30]. In a systematic review of the studies reporting mortality data for non-AKI patients and separately for patients in the Risk, Injury and Failure categories of the RIFLE classification, Ricci et al. [31] have found a stepwise increase in relative risk for death with increasing AKI severity (Risk 2.40, Injury 4.15, Failure 6.37) compared with non-AKI patients. Increasing severity of AKI is also associated with increased 1-month and 1-year mortality compared with non-AKI patients [32].

In addition, some survivors do not regain renal function and progress to ESKD. In the BEST Kidney Study, $13.8 \%$ of survivors progressed to ESKD [17]. The risk of ESKD is higher in elderly patients [33]. Reports on childhood AKI also suggest a higher risk of progressive renal disease by adolescence or adulthood [34]. 
Table 2. Ideal biomarkers for AKI

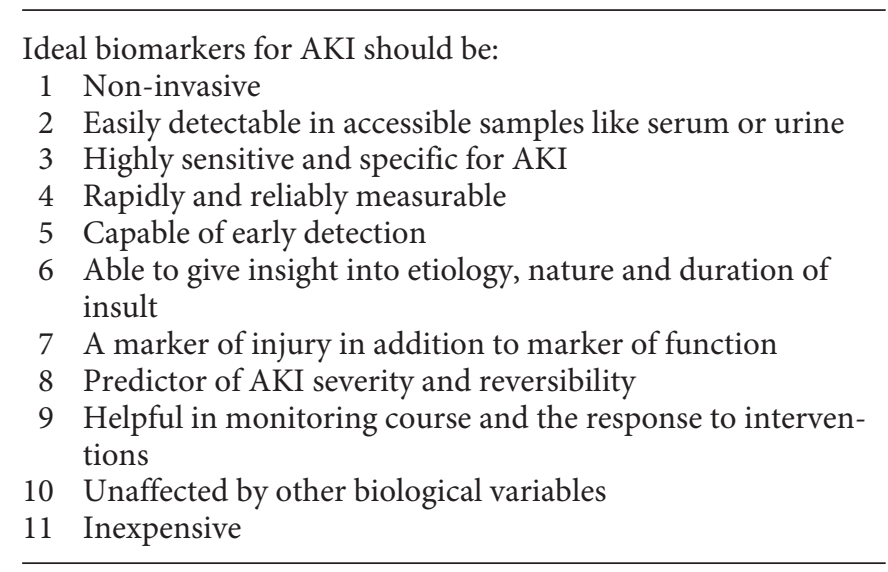

\section{Increased Cost}

As discussed earlier, development of AKI is associated with an increased length of ICU and hospital stay. In addition, many of these patients require RRT. Not surprisingly, AKI increases the cost of patient care. Even a slight increase in creatinine increases the cost manifold. Himmelfarb and Ikizler [35] have reported that an increase in creatinine by $0.3 \mathrm{mg} / \mathrm{dl}$ increases the cost by USD 4,886 , an increase by $0.5 \mathrm{mg} / \mathrm{dl}$ by USD 7,499, an increase by $1 \mathrm{mg} / \mathrm{dl}$ by USD 13,200, and an increase by $2 \mathrm{mg} / \mathrm{dl}$ by USD 22,023 per patient in hospital-acquired AKI. In patients with cardiac surgery-associated AKI, Dasta et al. [27] concluded that AKI accounted for a large chunk of postoperative costs which was incremental with the increasing severity of AKI. In patients with RIFLE class R, $73.3 \%$ of postoperative expenditure was related to treatment of AKI, while Class I accounted for $74.2 \%$ and Class $\mathrm{F}$ accounted for $93.7 \%$ of postoperative cost of care.

\section{Early Detection of AKI}

\section{Importance of Early Detection}

Although serum creatinine is typically used for diagnosis of AKI, it is an insensitive and unreliable biomarker during acute changes in kidney function [36]. The serum creatinine concentration does not increase until about half of the kidney function is lost. Although it is a reliable marker for detecting kidney dysfunction in patients with stable chronic kidney disease (CKD), it performs poorly in the setting of AKI [37]. The lack of an early biomarker has been a major impediment in developing newer preventive strategies for AKI [38]. Recent human studies have established the need for timely intervention in ameliorating renal dysfunction [39]. With the incidence of AKI reaching epidemic proportions, the need for newer biomarkers is urgent.

\section{Concept of Biomarker}

As is the case with any cellular insult, in AKI too, the injury begins by inducing molecular modifications later evolving into cellular damage. The cells start producing markers of injury and the clinical syndrome develops subsequently. It is postulated that the biological clock (biomarker expression) always precedes the clinical clock. The biological clock represents an earlier stage in progression to clinical syndrome [40]. Thus, detection of biomarker may provide the much needed window of opportunity for early intervention.

Possible newer biomarkers of AKI can be components of serum or urine or can be imaging studies or any other quantifiable parameter. New biomarkers are likely to be useful in facilitating early diagnosis, guiding targeted intervention and monitoring disease progression and resolution $[12,41]$. Desirable characteristics and expectations from an ideal biomarker for AKI are listed in table 2 .

\section{Emerging Biomarkers}

\section{Cystatin C}

Cystatin $\mathrm{C}$ is a cysteine protease inhibitor synthesized by all nucleated cells. It is freely filtered by the glomerulus, reabsorbed completely by PCT, and not secreted [42]. Unlike serum creatinine, the levels of cystatin $C$ are not affected by gender, age, race or muscle mass. It has been found useful both as serum or urinary biomarker.

In 85 critically ill patients at high risk for developing AKI, serum cystatin $\mathrm{C}$ was found to detect AKI almost 2 days earlier compared to detecting AKI by the RIFLE Classification using serum creatinine [43]. Many other studies have confirmed utility of serum cystatin $\mathrm{C}$ as a useful early biomarker $[44,45]$. Koyner et al. [46] found urinary cystatin $\mathrm{C}$ a very promising early (within $6 \mathrm{~h}$ after surgery) biomarker of AKI in adult cardiac surgery patients.

\section{Interleukin-18 (IL-18)}

IL-18 is a proinflammatory cytokine which is induced in PCT and is detected in urine following AKI. It was found to be an early predictor of AKI in patients with adult respiratory distress syndrome with an area under the curve (AUC) of 0.73. It was also found to be an inde- 
Table 3. Major studies reporting use of NGAL as an early biomarker in AKI

\begin{tabular}{llll}
$\begin{array}{l}\text { Group } \\
\text { (first author) }\end{array}$ & Year Patients & $\begin{array}{l}\text { Known Specimen Assay } \\
\text { timing } \\
\text { of insult }\end{array}$ \\
\hline
\end{tabular}

Clinical setting: cardiac surgery

Mishra [65] $2005 \quad 71$ children Yes

Plasma Western blot and $2 \mathrm{~h}$ postoperative uNGAL and pNGAL had high and urine research ELISA sensitivity and specificity for predicting AKI. AUC 0.998 for uNGAL and 0.91 for plasma

\begin{tabular}{lccllll}
\hline Dent [71] & 2007 & 120 children & Yes & Plasma & $\begin{array}{l}\text { Triage }{ }^{\circledR} \text { NGAL } \\
\text { device }\end{array}$ & $\begin{array}{l}\text { 2 h pNGAL had high sensitivity (0.84) and specificity } \\
\text { (0.94) for predicting AKI }\end{array}$ \\
\hline Bennett [79] & 2008 & 196 children & Yes & Urine & Architect ${ }^{\circledR}$ & $\begin{array}{l}\text { 2 h uNGAL had high sensitivity (0.82) and specificity } \\
\text { (0.90) for predicting AKI }\end{array}$ \\
\hline Wagener [73] & 2006 & 81 adults & Yes & Urine & Immunoblotting & $\begin{array}{l}\text { uNGAL levels were significantly increased in AKI } \\
\text { patients early (at 1 h) after surgery }\end{array}$ \\
\hline Xin [74] & 2008 & 33 adults & Yes & $\begin{array}{l}\text { Serum } \\
\text { and urine }\end{array}$ & ELISA & $\begin{array}{l}\text { 2 h uNGAL and IL-18 had high sensitivity and } \\
\text { specificity for predicting AKI. Postoperative serum } \\
\text { NGAL levels were not increased significantly }\end{array}$ \\
\hline Tuladhar [75] & 2009 & 50 adults & Yes & $\begin{array}{l}\text { Plasma } \\
\text { and urine }\end{array}$ & ELISA & $\begin{array}{l}\text { 2 h postoperative uNGAL and pNGAL had high } \\
\text { sensitivity and specificity for predicting AKI }\end{array}$ \\
\hline
\end{tabular}

\begin{tabular}{|c|c|c|c|c|c|c|}
\hline \multicolumn{7}{|c|}{ Clinical setting: contrast procedures } \\
\hline Hirsch [66] & 2007 & 91 children & Yes & $\begin{array}{l}\text { Plasma } \\
\text { and urine }\end{array}$ & ELISA & $\begin{array}{l}2 \mathrm{~h} \text { uNGAL and pNGAL had high specificity (1) and } \\
\text { sensitivity (0.73) for predicting AKI }\end{array}$ \\
\hline $\begin{array}{l}\text { Bachorzewska- } \\
\text { Gajewska [76] }\end{array}$ & 2007 & 100 adults & Yes & $\begin{array}{l}\text { Serum } \\
\text { and urine }\end{array}$ & ELISA & $\begin{array}{l}\text { Significant elevation of serum NGAL at } 2,4 \text { and } 8 \mathrm{~h} \\
\text { and uNGAL at } 4,8 \text { and } 24 \mathrm{~h} \text { after percutaneous } \\
\text { coronary intervention }\end{array}$ \\
\hline
\end{tabular}

\begin{tabular}{|c|c|c|c|c|c|c|}
\hline \multicolumn{7}{|c|}{ Clinical setting: intensive care unit (ICU) } \\
\hline Zappitelli [68] & 2007 & 140 children & No & Urine & ELISA & $\begin{array}{l}\text { uNGAL within } 24-48 \mathrm{~h} \text { of mechanical ventilation was } \\
\text { early predictor of AKI }\end{array}$ \\
\hline Wheeler [67] & 2008 & 143 children & No & Serum & ELISA & $\begin{array}{l}\text { Serum NGAL measured within } 24 \text { h of ICU admissior } \\
\text { was found to be a highly sensitive }(0.84) \text { but less } \\
\text { specific }(0.39) \text { predictor of AKI }\end{array}$ \\
\hline Makris [70] & 2009 & 31 adult & No & Urine & ELISA & $\begin{array}{l}\text { uNGAL at admission to ICU was a highly sensitive } \\
(0.91) \text { and specific }(0.96) \text { predictor of AKI }\end{array}$ \\
\hline \multicolumn{7}{|c|}{ Clinical setting: emergency department (ED) } \\
\hline Nickolas [69] & 2008 & 635 adults & No & Urine & Immunoblotting & $\begin{array}{l}\text { Single ED uNGAL measurement was predictive of } \\
\text { AKI and clinical outcomes. It helped to distinguish } \\
\text { AKI from prerenal azotemia and chronic kidney } \\
\text { disease }\end{array}$ \\
\hline
\end{tabular}

pendent predictor of mortality in this study [47]. In another study on patients undergoing cardiac surgery, urinary IL-18 levels increased $6 \mathrm{~h}$ after cardiopulmonary bypass $(\mathrm{CPB})$ and peaked at $12 \mathrm{~h}$ in patients who were diagnosed to have AKI 2 days later by creatinine criteria [48]. Elevated urinary IL-18 is more specific for ischemic $\mathrm{AKI}$ and its levels are not deranged in $\mathrm{CKD}$, urinary tract infections or nephrotoxic AKI [49]. However, a study by Haase et al. [50] did not find IL-18 to be a useful early predictor of AKI in a group of 100 adult patients undergoing cardiac surgery.

\section{Kidney Injury Molecule-1 (KIM-1)}

KIM-1 is a transmembrane protein which is markedly overexpressed in PCT in response to ischemic or toxic AKI in animal models $[51,52]$. In a cross-sectional study of 6 patients with ATN, KIM-1 was found to be highly expressed in proximal tubule cells in renal biopsies from 
these patients. Urinary KIM-1 helped to distinguish ischemic AKI from prerenal azotemia and CKD [53]. In a study of 40 children undergoing cardiac surgery, urinary KIM-1 levels were markedly enhanced at $12 \mathrm{~h}$, with an AUC of 0.83 for predicting AKI [54]. In another study, urinary KIM-1 along with urinary $N$-acetyl- $\beta$-(D)-glucosaminidase (NAG) were found to be predictors of RRT and mortality in AKI [55].

Neutrophil Gelatinase-Associated Lipocalin (NGAL)

NGAL is the most promising among all emerging biomarkers for AKI (table 3) [56]. It is a protein of the lipocalin family and is composed of $8 \beta$-strands that form a $\beta$-barrel enclosing a calyx [57]. The calyx binds and transports low-molecular-weight substances. NGAL is expressed by neutrophils and other epithelial cells including PCT [58]. NGAL gene expression is demonstrated in various human tissues like uterus, prostate, salivary gland, lung, trachea, stomach, colon, and kidney [59]. Understanding its role in human physiology and disease is rapidly increasing. Recent findings suggesting its role in binding siderophores (small iron-carrying molecules) and its expression in various pathological states like AKI have prompted a large number of studies [60]. Human NGAL consists of a polypeptide chain of 178 amino acids with a molecular mass to $25 \mathrm{kDa}$. It occurs predominantly in a monomeric form with a small percentage occurring as a dimer or trimer.

\section{NGAL as a Biomarker in AKI}

\section{Early Detection of AKI}

As discussed earlier, early detection of AKI is of paramount importance. Improvement in clinical outcomes of the patients with acute coronary syndrome in the last few decades is aided by the availability of a panel of biomarkers. Absence of a similar panel in AKI is a major impediment in improving clinical outcomes. NGAL shows a promise of becoming the equivalent of troponin in AKI and is likely to be an important component of the 'AKI panel' [12]. In a study by Mishra et al. [61], NGAL was found to be one of the seven genes which were highly upregulated in mouse models of renal ischemia reperfusion injury. NGAL was detected in the very first urine sample within $2 \mathrm{~h}$ following ischemia. Its levels correlated to the duration of ischemia. Later it was identified as a marker of cisplatin nephrotoxicity in an animal model [62]. Further experiments $[63,64]$ validated NGAL as one of the earliest and most robustly induced proteins in kidneys following ischemic and nephrotoxic insults. Many clinical studies followed this novel observation. In a study of 71 children undergoing CPB, urinary NGAL (uNGAL) and plasma NGAL (pNGAL) at $2 \mathrm{~h}$ after CPB were found to be powerful independent predictors of AKI with extraordinary AUC of 0.998 for UNGAL and 0.91 for pNGAL [65]. In a prospective study of 91 children with congenital heart disease undergoing elective cardiac catheterization with contrast administration, both uNGAL and pNGAL predicted contrast-induced nephropathy within $2 \mathrm{~h}$ of contrast administration [66]. The AUC for prediction of contrast nephropathy (at $2 \mathrm{~h}$ ) was found to be 0.92 for uNGAL and 0.91 for pNGAL.

After initial encouraging results, NGAL has been tested as an early biomarker in a variety of clinical settings. Wheeler et al. [67] studied serum NGAL in 143 critically ill children with systemic inflammatory response syndrome (SIRS) or septic shock within $24 \mathrm{~h}$ of admission to an ICU. Serum NGAL was found to be highly sensitive but non-specific (sensitivity $84 \%$, specificity 39\%) biomarker of AKI. It was also found to correlate with the severity of systemic disease with higher values in patients with septic shock than with SIRS and healthy controls. Zappitelli et al. [68] studied uNGAL in 140 critically ill mechanically ventilated patients. A significant rise $(>6$ times) in levels of uNGAL occurred 2 days earlier than a $50 \%$ increase in serum creatinine levels. uNGAL levels increased in a stepwise fashion with worsening RIFLE class.

In a recently published study [69], a single measurement of uNGAL in the emergency department in 635 patients was found to be highly sensitive and specific (sensitivity 90\%, specificity 99\%) in diagnosing AKI. Additionally, uNGAL level helped to distinguish patients with AKI from other morbid conditions with elevated creatinine like prerenal azotemia and CKD. Makris et al. [70] have found uNGAL as an early marker of AKI in critically ill polytrauma patients. Many other studies have found NGAL to be a reliable early biomarker for AKI [7176].

\section{Correlation with Risk Factors for AKI}

In a large prospective study, Wagener et al. [77] studied 426 adult patients undergoing cardiac surgery and found elevation of UNGAL to correlate with CPB time and aortic cross-clamp time (AXT). CPB time and AXT are indices of renal hypoperfusion and are established risk factors for development of AKI [78]. Serum creatinine did not show any correlation with CPB time or AXT. 


\section{Prediction of Outcome}

In addition to its utility in establishing diagnosis of AKI as early as possible [56], some studies have evaluated NGAL for risk stratification and prognosis. Dent et al. [71] found the 2-hour postoperative pNGAL level a reliable predictor of duration of AKI and length of hospital stay while the 12-hour pNGAL level was a predictor of mortality. Similarly, Bennett et al. [79] found the 2-hour uNGAL a reliable predictor of severity and duration of AKI, length of hospital stay, RRT requirement and mortality in 196 children undergoing CPB. Single uNGAL measurement in the emergency department was found to predict the need for nephrology consultation, ICU admission and dialysis in another study [69]. However, in a study of pediatric hemolytic uremic syndrome cases, pNGAL levels were unable to reliably predict the need for RRT regardless of cut-off values examined. In the same study, uNGAL levels within first 5 days of hospitalization showed high sensitivity but low specificity in predicting need for RRT [80].

\section{NGAL as a Protective Agent in AKI}

By virtue of its ability to act as a growth factor, NGAL has also been found to have a renoprotective effect in acute ischemic renal injury in an animal model [81]. In mouse models of ischemia reperfusion injury, purified NGAL was injected intravenously at doses of 50,100 or $250 \mu \mathrm{g}$ of NGAL or an equal amount of normal saline for comparison. The animals receiving $250 \mu \mathrm{g}$ NGAL showed best protection from tubular damage and azotemia. This novel observation needs to be validated in a clinical study.

\section{Measurement of NGAL}

\section{Methods of Measurement}

In the initial phase, NGAL estimation was carried out by Western blot technique. Subsequent clinical studies have utilized ELISA-based techniques using the commercially available kit from Antibodyshop, Gentofte, Denmark [72, 77].

A standardized point-of-care Triage ${ }^{\circledR}$ NGAL device (Biosite, Inc., San Diego, Calif., USA) has been devised for the measurement of pNGAL. It was found to correlate well with research ELISA in a pilot study of 40 plasma samples and 12 calibrations. Its usage was subsequently validated in a study of 120 patients undergoing $\mathrm{CPB}$ of which 45 patients developed AKI [71]. Mean pNGAL concentrations increased 3 -fold within $2 \mathrm{~h}$, while the diagnosis of AKI using serum creatinine concentration was delayed by 2-3 days. Using a cut-off value of $150 \mathrm{ng} / \mathrm{ml}$ for the 2-hour pNGAL concentration, the AUC was 0.96, sensitivity $84 \%$ and specificity $94 \%$ for prediction of AKI. The assay needs only microliter quantities of whole blood or plasma and quantitative results are available within 15 min, thus making bedside testing of pNGAL feasible.

Similarly, an uNGAL assay Architect ${ }^{\circledR}$ analyzer (Abbott Diagnostics, Ill., USA) is available for clinical application. In a pilot study with 136 urine samples and 6 calibration standards, NGAL concentrations by the Architect ${ }^{\circledR}$ analyzer correlated with research ELISA. Its usage was subsequently validated in a study of 196 patients undergoing CPB [79]. Mean uNGAL concentrations increased 15 -fold within $2 \mathrm{~h}$, and by 25 -fold at 4 and $6 \mathrm{~h}$ after $\mathrm{CPB}$. The diagnosis of AKI using serum creatinine concentration was delayed by $2-3$ days after CPB. Using a cut-off value of $100 \mathrm{~g} / \mathrm{l}$ for the 2-hour uNGAL concentration, the AUC was 0.95 , sensitivity $82 \%$ and specificity $90 \%$ for prediction of AKI [79]. The assay is found to be easy to perform with no manual pretreatment steps [38]. The assay needs only $150 \mu$ l of urine and quantitative results are available within $35 \mathrm{~min}$, thus making it an easily deployable tool in testing uNGAL for early diagnosis of AKI.

\section{Indications for Measurement of NGAL}

Results from recent clinical studies suggest that NGAL measurement (both urine and plasma) might be useful in early detection of AKI. Measurement of NGAL may present an unique opportunity for timely diagnosis and intervention in order to protect kidney from further insults in numerous clinical situations like critical illness, sepsis and septic shock [67], oliguria [82], contrast procedures $[66,72]$, CPB $[65,73]$, especially if CPB and AXT time is prolonged [77], polytrauma [70], complex cardiovascular surgeries and deep hypothermia [83]. Measurement of NGAL might be useful in randomized control trials assessing efficacy of early intervention for AKI. Diagnosis of AKI at an early stage might improve patient selection for such trials. NGAL has also been found to be a useful tool in disease monitoring in other renal diseases, delayed graft function [84], lupus nephritis [85, 86], IgA nephropathy [87] and polycystic kidney disease [88]. In addition, it has been found to be a biomarker in many other non-renal conditions like brain tumor [89], inflammatory bowel disease [90] and pre-eclampsia [91]. 
Factors Influencing NGAL Measurement

In a study from 426 adults undergoing CPB [77], uNGAL levels were significantly elevated in all patients (with or without $\mathrm{AKI}$ ), raising a concern whether $\mathrm{CPB}$ initiates inflammation and activation of neutrophils leading to increased NGAL levels. In a recent in vitro study by Bobek et al. [92], NGAL was found to be ultrafiltered and adsorbed by polysulfone membranes, reducing its blood levels. As many patients with AKI undergo RRT, this finding if confirmed in vivo, can be potentially confounding in monitoring the clinical course of AKI using NGAL.

\section{Limitations of NGAL as a Biomarker for AKI}

Although NGAL appears to be a promising biomarker for predicting AKI and its outcome, most of the literature has emerged from single centers and from homogenous patient populations [93]. Large multicenter studies are required for further validation of its use in heterogenous patient populations and for defining cut-off values for di- agnosis and outcomes of AKI. Various other factors like $\mathrm{RRT}$, underlying CKD, and CPB might influence its measurement as discussed earlier.

\section{Conclusions}

Recent studies in the field of early detection of AKI have proposed many biomarkers for early detection of AKI. NGAL appears to be the most promising of all biomarkers. It can be used in tandem with other newer biomarkers like cystatin C, KIM-1 or IL-18, and together they may represent a 'kidney panel' in the future. Differential expression of these markers may potentially help to distinguish between various types of insults, provide information about duration of injury, predict clinical outcome and help to monitor treatment response. However, until now these markers have been tested in small studies and specific clinical situations. Future studies in large cohorts with multiple clinical situations might substantiate the utility of these markers.

\section{References}

1 Smith H: The Kidney: Structure and Function in Health and Disease. London, Oxford University Press, 1964.

-2 Lameire N, Van Biesen W, Vanholder R: Acute renal failure. Lancet 2005;365:417430.

-3 Kellum JA, Levin N, Bouman C, Lameire N: Developing a consensus classification system for acute renal failure. Curr Opin Crit Care 2002;8:509-514.

4 Bellomo R, Kellum J, Ronco C: Acute renal failure: time for consensus. Intensive Care Med 2001;27:1685-1688.

5 Bellomo R Ronco C, Kellum JA, the ADQI Workgroup: Acute renal failure - definition, outcome measures, animal models, fluid therapy and information technology needs: The Second International Consensus Conference of the Acute Dialysis Quality Initiative (ADQI) Group. Crit Care 2004;8:R204$\mathrm{R} 212$.

-6 Hoste EA, Clermont G, Kersten A, Venkataraman R, Angus DC, De Bacquer D, Kellum JA: Rifle criteria for acute kidney injury are associated with hospital mortality in critically ill patients: a cohort analysis. Crit Care 2006; 10:R73.

7 Hoste EA, Kellum JA: Rifle criteria provide robust assessment of kidney dysfunction and correlate with hospital mortality. Crit Care Med 2006;34:2016-2017.
-8 Cruz DN, Bolgan I, Perazella MA, Bonello M, de Cal M, Corradi V, Polanco N, Ocampo C, Nalesso F, Piccinni P, Ronco C: NorthEast Italian Prospective Hospital Renal Outcome Survey on Acute Kidney Injury (NEIPHROS-AKI): targeting the problem with the rifle criteria. Clin J Am Soc Nephrol 2007;2:418-425.

9 Mehta RL, Kellum JA, Shah SV, Molitoris BA, Ronco C, Warnock DG, Levin A, Acute Kidney Injury Network: Report of an initiative to improve outcomes in acute kidney injury. Crit Care 2007;11:R31.

10 Lopes JA, Fernandes P, Jorge S, Goncalves S, Alvarez A, Costa e Silva Z, Franca C, Prata MM: Acute kidney injury in intensive care unit patients: a comparison between the RIFLE and the Acute Kidney Injury Network classifications. Crit Care 2008;12:R110.

11 Bagshaw SM, George C, Bellomo R: A comparison of the RIFLE and AKIN criteria for acute kidney injury in critically ill patients. Nephrol Dial Transplant 2008;23:15691574.

12 Devarajan P: Emerging biomarkers of acute kidney injury. Contrib Nephrol. Basel, Karger, 2007, vol 156, pp 203-212.

13 Feest TG, Round A, Hamad S: Incidence of severe acute renal failure in adults: results of a community-based study. BMJ 1993;306: 481-483.
14 Hsu CY, McCulloch CE, Fan D, Ordonez JD, Chertow GM, Go AS: Community-based incidence of acute renal failure. Kidney Int 2007;72:208-212.

15 Metnitz PG, Krenn CG, Steltzer H, Lang T, Ploder J, Lenz K, Le Gall JR, Druml W: Effect of acute renal failure requiring renal replacement therapy on outcome in critically ill patients. Crit Care Med 2002;30:2051-2058.

16 Schrier RW, Wang W: Acute renal failure and sepsis. N Engl J Med 2004;351:159-169.

17 Uchino S, Kellum JA, Bellomo R, Doig GS, Morimatsu H, Morgera S, Schetz M, Tan I, Bouman C, Macedo E, Gibney N, Tolwani A, Ronco C: Acute renal failure in critically ill patients: a multinational, multicenter study. JAMA 2005;294:813-818.

18 Ali T, Khan I, Simpson W, Prescott G, Townend J, Smith W, Macleod A: Incidence and outcomes in acute kidney injury: a comprehensive population-based study. J Am Soc Nephrol 2007;18:1292-1298.

19 Blantz RC: Pathophysiology of pre-renal azotemia. Kidney Int 1998;53:512-523.

20 Nash K, Hafeez A, Hou S: Hospital-acquired renal insufficiency. Am J Kidney Dis 2002; 39:930-936.

21 Cerda J, Lameire N, Eggers P, Pannu N, Uchino S, Wang H, Bagga A, Levin A: Epidemiology of acute kidney injury. Clin J Am Soc Nephrol 2008;3:881-886. 
22 Barsoum RS: Tropical acute renal failure. Contrib Nephrol. Basel, Karger, 2004, vol 144, pp 44-52.

23 Devarajan P: Update on mechanisms of ischemic acute kidney injury. J Am Soc Nephrol 2006;17:1503-1520.

-24 Wan L, Bagshaw SM, Langenberg C, Saotome T, May C, Bellomo R: Pathophysiology of septic acute kidney injury: What do we really know? Crit Care Med 2008;36:S198S203.

-25 Safirstein RL: Acute renal failure: from renal physiology to the renal transcriptome. Kidney Int Suppl 2004;S62-S66.

-26 Kuitunen A, Vento A, Suojaranta-Ylinen R, Pettila V: Acute renal failure after cardiac surgery: evaluation of the RIFLE Classification. Ann Thorac Surg 2006;81:542-546.

-27 Dasta JF, Kane-Gill SL, Durtschi AJ, Pathak DS, Kellum JA: Costs and outcomes of acute kidney injury following cardiac surgery. Nephrol Dial Transplant 2008;23:19701974.

-28 Star RA: Treatment of acute renal failure. Kidney Int 1998;54:1817-1831.

-29 Ympa YP, Sakr Y, Reinhart K, Vincent JL: Has mortality from acute renal failure decreased? A systematic review of the literature. Am J Med 2005;118:827-832.

-30 Bagshaw SM, George C, Dinu I, Bellomo R: A multi-centre evaluation of the RIFLE criteria for early acute kidney injury in critically ill patients. Nephrol Dial Transplant 2008; 23:1203-1210.

-31 Ricci Z, Cruz D, Ronco C: The RIFLE criteria and mortality in acute kidney injury: a systematic review. Kidney Int 2008;73:538546.

>32 Bagshaw SM, Mortis G, Doig CJ, GodinezLuna T, Fick GH, Laupland KB: One-year mortality in critically ill patients by severity of kidney dysfunction: a population-based assessment. Am J Kidney Dis 2006;48:402409.

-33 Bhandari S, Turney JH: Survivors of acute renal failure who do not recover renal function. QJM 1996;89:415-421.

-34 Shaw NJ, Brocklebank JT, Dickinson DF, Wilson N, Walker DR: Long-term outcome for children with acute renal failure following cardiac surgery. Int J Cardiol 1991;31: 161-165.

\$3 Himmelfarb J, Ikizler TA: Acute kidney injury: changing lexicography, definitions, and epidemiology. Kidney Int 2007;71:971976.

>36 Bellomo R, Kellum JA, Ronco C: Defining acute renal failure: physiological principles. Intensive Care Med 2004;30:33-37.

-37 Coca SG, Parikh CR: Urinary biomarkers for acute kidney injury: perspectives on translation. Clin J Am Soc Nephrol 2008;3:481490
38 Devarajan P: Neutrophil gelatinase-associated lipocalin (NGAL): a new marker of kidney disease. Scand J Clin Lab Invest Suppl 2008;241:89-94.

39 Schrier RW: Need to intervene in established acute renal failure. J Am Soc Nephrol 2004; 15:2756-2758

40 Ronco C: NGAL: an emerging biomarker of acute kidney injury. Int J Artif Organs 2008; 31:199-200.

41 Vaidya VS, Ferguson MA, Bonventre JV: Biomarkers of acute kidney injury. Annu Rev Pharmacol Toxicol 2008;48:463-493.

42 Nguyen MT, Devarajan P: Biomarkers for the early detection of acute kidney injury. Pediatr Nephrol 2008;23:2151-2157.

43 Herget-Rosenthal S, Marggraf G, Husing J, Goring F, Pietruck F, Janssen O, Philipp T, Kribben A: Early detection of acute renal failure by serum cystatin C. Kidney Int 2004; 66:1115-1122.

44 Villa P, Jimenez M, Soriano MC, Manzanares J, Casasnovas P: Serum cystatin C concentration as a marker of acute renal dysfunction in critically ill patients. Crit Care 2005 9:R139-R143.

45 Delanaye P, Lambermont B, Chapelle JP, Gielen J, Gerard P, Rorive G: Plasmatic cystatin $\mathrm{C}$ for the estimation of glomerular filtration rate in intensive care units. Intensive Care Med 2004;30:980-983.

46 Koyner JL, Bennett MR, Worcester EM, Ma Q, Raman J, Jeevanandam V, Kasza KE, O'Connor MF, Konczal DJ, Trevino S, Devarajan P, Murray PT: Urinary cystatin C as an early biomarker of acute kidney injury following adult cardiothoracic surgery. Kidney Int 2008;74:1059-1069.

47 Parikh CR, Abraham E, Ancukiewicz M, Edelstein CL: Urine IL-18 is an early diagnostic marker for acute kidney injury and predicts mortality in the intensive care unit. J Am Soc Nephrol 2005;16:3046-3052.

48 Parikh CR, Mishra J, Thiessen-Philbrook H, Dursun B, Ma Q, Kelly C, Dent C, Devarajan P, Edelstein CL: Urinary IL-18 is an early predictive biomarker of acute kidney injury after cardiac surgery. Kidney Int 2006;70:199203.

49 Parikh CR, Devarajan P: New biomarkers of acute kidney injury. Crit Care Med 2008;36: S159-S165.

50 Haase M, Bellomo R, Story D, Davenport P, Haase-Fielitz A: Urinary interleukin-18 does not predict acute kidney injury after adult cardiac surgery: a prospective observational cohort study. Crit Care 2008;12:R96.

51 Ichimura T, Bonventre JV, Bailly V, Wei H, Hession CA, Cate RL, Sanicola M: Kidney injury molecule-1 (KIM-1), a putative epithelial cell adhesion molecule containing a novel immunoglobulin domain, is upregulated in renal cells after injury. J Biol Chem 1998;273:4135-4142.
52 Ichimura T, Hung CC, Yang SA, Stevens JL, Bonventre JV: Kidney injury molecule-1: a tissue and urinary biomarker for nephrotoxicant-induced renal injury. Am J Physiol Renal Physiol 2004;286:F552-F563.

53 Han WK, Bailly V, Abichandani R, Thadhani R, Bonventre JV: Kidney injury molecule-1 (KIM-1): a novel biomarker for human renal proximal tubule injury. Kidney Int 2002;62:237-244

54 Vaidya VS, Ramirez V, Ichimura T, Bobadilla NA, Bonventre JV: Urinary kidney injury molecule-1: a sensitive quantitative biomarker for early detection of kidney tubular injury. Am J Physiol Renal Physiol 2006;290: F517-F529.

55 Liangos O, Perianayagam MC, Vaidya VS, Han WK, Wald R, Tighiouart H, MacKinnon RW, Li L, Balakrishnan VS, Pereira BJ, Bonventre JV, Jaber BL: Urinary $N$-acetyl- $\beta$ (D)-glucosaminidase activity and kidney injury molecule-1 level are associated with adverse outcomes in acute renal failure. J Am Soc Nephrol 2007;18:904-912.

56 Ronco C: N-GAL: Diagnosing AKI as soon as possible. Crit Care 2007;11:173.

57 Flower DR, North AC, Sansom CE: The lipocalin protein family: structural and sequence overview. Biochim Biophys Acta 2000;1482: $9-24$

58 Uttenthal O: NGAL: a marker molecule for the distressed kidney? Clin Lab Internat 2005;29:39-41.

59 Cowland JB, Borregaard N: Molecular characterization and pattern of tissue expression of the gene for neutrophil gelatinase-associated lipocalin from humans. Genomics 1997; 45:17-23.

60 Schmidt-Ott KM, Mori K, Kalandadze A, Li JY, Paragas N, Nicholas T, Devarajan P, Barasch J: Neutrophil gelatinase-associated lipocalin-mediated iron traffic in kidney epithelia. Curr Opin Nephrol Hypertens 2006; 15:442-449.

61 Mishra J, Ma Q, Prada A, Mitsnefes M, Zahedi K, Yang J, Barasch J, Devarajan P: Identification of neutrophil gelatinase-associated lipocalin as a novel early urinary biomarker for ischemic renal injury. J Am Soc Nephrol 2003;14:2534-2543.

62 Mishra J, Mori K, Ma Q, Kelly C, Barasch J, Devarajan P: Neutrophil gelatinase-associated lipocalin: a novel early urinary biomarker for cisplatin nephrotoxicity. Am J Nephrol 2004;24:307-315.

-63 Mori K, Lee HT, Rapoport D, Drexler IR, Foster K, Yang J, Schmidt-Ott KM, Chen X, Li JY, Weiss S, Mishra J, Cheema FH, Markowitz G, Suganami T, Sawai K, Mukoyama M, Kunis C, D’Agati V, Devarajan P, Barasch $\mathrm{J}$ : Endocytic delivery of lipocalin-siderophore-iron complex rescues the kidney from ischemia-reperfusion injury. J Clin Invest 2005; 115:610-621. 
64 Devarajan R: Novel biomarkers for the early prediction of acute kidney injury. Cancer Ther 2005;3:477-488.

- 65 Mishra J, Dent C, Tarabishi R, Mitsnefes MM, Ma Q, Kelly C, Ruff SM, Zahedi K, Shao M, Bean J, Mori K, Barasch J, Devarajan P: Neutrophil gelatinase-associated lipocalin (NGAL) as a biomarker for acute renal injury after cardiac surgery. Lancet 2005;365:12311238.

-66 Hirsch R, Dent C, Pfriem H, Allen J, Beekman RH 3rd, Ma Q, Dastrala S, Bennett M, Mitsnefes M, Devarajan P: NGAL is an early predictive biomarker of contrast-induced nephropathy in children. Pediatr Nephrol 2007;22:2089-2095.

-67 Wheeler DS, Devarajan P, Ma Q, Harmon K, Monaco M, Cvijanovich N, Wong HR: Serum neutrophil gelatinase-associated lipocalin (NGAL) as a marker of acute kidney injury in critically ill children with septic shock. Crit Care Med 2008;36:1297-1303.

-68 Zappitelli M, Washburn KK, Arikan AA, Loftis L, Ma Q, Devarajan P, Parikh CR, Goldstein SL: Urine neutrophil gelatinaseassociated lipocalin is an early marker of acute kidney injury in critically ill children: a prospective cohort study. Crit Care 2007; 11:R84.

69 Nickolas TL, O'Rourke MJ, Yang J, Sise ME, Canetta PA, Barasch N, Buchen C, Khan F, Mori K, Giglio J, Devarajan P, Barasch J: Sensitivity and specificity of a single emergency department measurement of urinary neutrophil gelatinase-associated lipocalin for diagnosing acute kidney injury. Ann Intern Med 2008;148:810-819.

-70 Makris K, Markou N, Evodia E, Dimopoulou E, Drakopoulos I, Ntetsika K, Rizos D, Baltopoulos G, Haliassos A: Urinary neutrophil gelatinase-associated lipocalin (NGAL) as an early marker of acute kidney injury in critically ill multiple trauma patients. Clin Chem Lab Med 2009;47:79-82.

-71 Dent CL, Ma Q, Dastrala S, Bennett M, Mitsnefes MM, Barasch J, Devarajan P: Plasma neutrophil gelatinase-associated lipocalin predicts acute kidney injury, morbidity and mortality after pediatric cardiac surgery: a prospective uncontrolled cohort study. Crit Care 2007;11:R127.

-72 Bachorzewska-Gajewska H, Malyszko J, Sitniewska E, Malyszko JS, Dobrzycki S: Neutrophil gelatinase-associated lipocalin (NGAL) correlations with cystatin C, serum creatinine and EGFR in patients with normal serum creatinine undergoing coronary angiography. Nephrol Dial Transplant 2007; 22:295-296.
73 Wagener G, Jan M, Kim M, Mori K, Barasch JM, Sladen RN, Lee HT: Association between increases in urinary neutrophil gelatinaseassociated lipocalin and acute renal dysfunction after adult cardiac surgery. Anesthesiology 2006;105:485-491.

74 Xin C, Yulong X, Yu C, Changchun C, Feng Z, Xinwei M: Urine neutrophil gelatinaseassociated lipocalin and interleukin-18 predict acute kidney injury after cardiac surgery. Ren Fail 2008;30:904-913.

75 Tuladhar SM, Puntmann VO, Soni M, Punjabi PP, Bogle RG: Rapid detection of acute kidney injury by plasma and urinary neutrophil gelatinase-associated lipocalin after cardiopulmonary bypass. JCardiovasc Pharmacol 2009;53:261-266.

76 Bachorzewska-Gajewska H, Malyszko J, Sitniewska E, Malyszko JS, Pawlak K, Mysliwiec M, Lawnicki S, Szmitkowski M, Dobrzycki S: Could neutrophil-gelatinase-associated lipocalin and cystatin $\mathrm{C}$ predict the development of contrast-induced nephropathy after percutaneous coronary interventions in patients with stable angina and normal serum creatinine values? Kidney Blood Press Res 2007;30:408-415.

77 Wagener G, Gubitosa G, Wang S, Borregaard N, Kim M, Lee HT: Urinary neutrophil gelatinase-associated lipocalin and acute kidney injury after cardiac surgery. Am J Kidney Dis 2008;52:425-433.

78 Fischer UM, Weissenberger WK, Warters RD, Geissler HJ, Allen SJ, Mehlhorn U: Impact of cardiopulmonary bypass management on postcardiac surgery renal function. Perfusion 2002;17:401-406.

79 Bennett M, Dent CL, Ma Q, Dastrala S, Grenier F, Workman R, Syed H, Ali S, Barasch J, Devarajan P: Urine NGAL predicts severity of acute kidney injury after cardiac surgery: a prospective study. Clin J Am Soc Nephrol 2008;3:665-673

-80 Trachtman H, Christen E, Cnaan A, Patrick J, Mai V, Mishra J, Jain A, Bullington N, Devarajan P: Urinary neutrophil gelatinase-associated lipocalcin in D+HUS: a novel marker of renal injury. Pediatr Nephrol 2006;21: 989-994.

81 Mishra J, Mori K, Ma Q, Kelly C, Yang J Mitsnefes M, Barasch J, Devarajan P: Amelioration of ischemic acute renal injury by neutrophil gelatinase-associated lipocalin. J Am Soc Nephrol 2004;15:3073-3082.

82 Bagshaw SM, Bellomo R, Kellum JA: Oliguria, volume overload, and loop diuretics. Crit Care Med 2008;36:S172-S178.
83 Arnaoutakis GJ, Bihorac A, Martin TD, Hess PJ Jr, Klodell CT, Ejaz AA, Garvan C, Tribble CG, Beaver TM: RIFLE criteria for acute kidney injury in aortic arch surgery. J Thorac Cardiovasc Surg 2007;134:1554-1561.

84 Parikh CR, Jani A, Mishra J, Ma Q, Kelly C, Barasch J, Edelstein CL, Devarajan P: Urine NGAL and IL-18 are predictive biomarkers for delayed graft function following kidney transplantation. Am J Transplant 2006;6: 1639-1645.

-85 Brunner HI, Mueller M, Rutherford C, Passo MH, Witte D, Grom A, Mishra J, Devarajan P: Urinary neutrophil gelatinase-associated lipocalin as a biomarker of nephritis in childhood-onset systemic lupus erythematosus. Arthritis Rheum 2006;54:2577-2584.

- 86 Suzuki M, Wiers KM, Klein-Gitelman MS, Haines KA, Olson J, Onel KB, O’Neil K, Passo MH, Singer NG, Tucker L, Ying J, Devarajan P, Brunner HI: Neutrophil gelatinase-associated lipocalin as a biomarker of disease activity in pediatric lupus nephritis. Pediatr Nephrol 2008;23:403-412.

87 Ding H, He Y, Li K, Yang J, Li X, Lu R, Gao W: Urinary neutrophil gelatinase-associated lipocalin (NGAL) is an early biomarker for renal tubulointerstitial injury in IgA nephropathy. Clin Immunol 2007;123:227234.

88 Bolignano D, Coppolino G, Campo S, Aloisi C, Nicocia G, Frisina N, Buemi M: Neutrophil gelatinase-associated lipocalin in patients with autosomal-dominant polycystic kidney disease. Am J Nephrol 2007;27:373378.

89 Smith ER, Zurakowski D, Saad A, Scott RM, Moses MA: Urinary biomarkers predict brain tumor presence and response to therapy. Clin Cancer Res 2008;14:2378-2386.

90 Manfredi MA, Zurakowski D, Rufo PA, Walker TR, Fox VL, Moses MA: Increased incidence of urinary matrix metalloproteinases as predictors of disease in pediatric patients with inflammatory bowel disease. Inflamm Bowel Dis 2008;14:1091-1096.

91 D’Anna R, Baviera G, Giordano D, Todarello G, Corrado F, Buemi M: Second trimester neutrophil gelatinase-associated lipocalin as a potential prediagnostic marker of preeclampsia. Acta Obstet Gynecol Scand 2008; 87:1370-1373.

92 Bobek I, de Cal M, Cruz D, Nalesso F, Lentini P, Corradi V, Happio M, Ronco C: In vitro removal of NGAL by extracorporeal therapy. J Am Soc Nephrol 2008; 19:457A.

$\$ 93$ Devarajan P: Neutrophil gelatinase-associated lipocalin - an emerging troponin for kidney injury. Nephrol Dial Transplant 2008;23:3737-3743. 